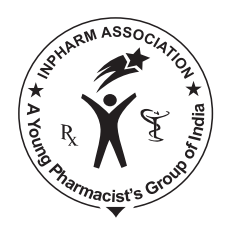

\title{
JVP
}

\section{Simultaneous Quantitative Analysis of Olmesartan Medoxomil and Amlodipine Besylate in Plasma by High-performance Liquid Chromatography Technique}

\author{
Shah SK, Asnani AJ'1, Kawade DP ${ }^{1}$, Dangre SC ${ }^{2}$, Arora SK ${ }^{3}$, Yende SR \\ Department of Pharmaceutical Chemistry, Smt. Kishoritai Bhoyar College of Pharmacy, Nagpur, \\ ${ }^{1}$ J. L. Chaturvedi College of Pharmacy, MIDC, Nagpur, ${ }^{2}$ Sharad Pawar College of Pharmacy, Wanadongari, \\ Nagpur, ${ }^{3}$ Department of Pharmaceutical Science, Rashtrasant Tukadoji Maharaj Nagpur University, \\ Amravati Road, Nagpur, ${ }^{4}$ Gurunanak College of Pharmacy, Nagpur, Maharashtra, India
}

Address for correspondence: Prof. Sapan Kamleshkumar Shah; E-mail: shah.sapan@ rediffmail.com

\begin{abstract}
A rapid, simple and sensitive high-performance liquid chromatography (HPLC) method has been developed for quantification of olmesartan medoxomil (OLM) and amlodipine besylate (AM) in plasma. The assay enables the measurement of OLM and AM for therapeutic drug monitoring with a minimum detectable limit of $2 \mathrm{ng} \mathrm{mL}$. The method involves a simple, one-step extraction procedure and analytical recovery was above $50 \%$. The separation was performed on an analytical $250 \times 4.6 \mathrm{~mm}$ Eurospher $100^{-5} \mathrm{C} 18$ column. The wavelength was set at $239 \mathrm{~nm}$. The mobile phase was a mixture of acetonitrile:0.05 M ammonium acetate buffer: $0.1 \mathrm{~mL}$ triethylamine at $\mathrm{pH} 6.8$ was selected at a flow rate of $1.0 \mathrm{~mL} / \mathrm{min}$. The calibration curve for the determination of OLM and AM in plasma was linear over the range $2-2500$ and $8-10,000 \mathrm{ng} / \mathrm{mL} \mathrm{AM}$ and OLM. The coefficients of variation for interday and intraday assay were found to be $<15 \%$. The method can be applied to a pharmacokinetic and pharmacodynamic study of OLM and AM in a combined dosage form.
\end{abstract}

Key words: Amlodipine besylate, high-performance liquid chromatography, olmesartan medoxomil, plasma

\section{INTRODUCTION}

Amlodipine, R, S-2-[(2-aminoethoxy)methyl]-4(2-chlorophenyl)-ethoxycarbonyl-5-methoxy-carbonyl-6methyl-1, 4-dihydropyridine [Figure 1], is a potent calcium

\begin{tabular}{|l|l|}
\hline \multicolumn{2}{|c|}{ Access this article online } \\
\hline Quick Response Code: & \multirow{2}{*}{ Website: } \\
\hline & www.jyoungpharm.in \\
& DOI: \\
\hline
\end{tabular}

channel blocker used in treatment of hypertension and angina pectoris. ${ }^{[1]}$ Amlodipine is well absorbed following oral administration with peak blood concentrations occurring after $6-12 \mathrm{~h}$. The bioavailability is about $60-65 \%$. It has a prolonged terminal elimination half-life of 35-50 h, and steady-state plasma concentrations are not achieved until after $7-8$ days of administration. Amlodipine is extensively metabolized in the liver; metabolites are mostly excreted in urine together with $<10 \%$ of a dose as unchanged drug. ${ }^{[2,3]}$ Several analytical methods for quantifying of amlodipine in biological fluids have been reported; such as capillary gas chromatography (GC) with electron capture detection, ${ }^{[4,5]}$ GC with electron-impact 


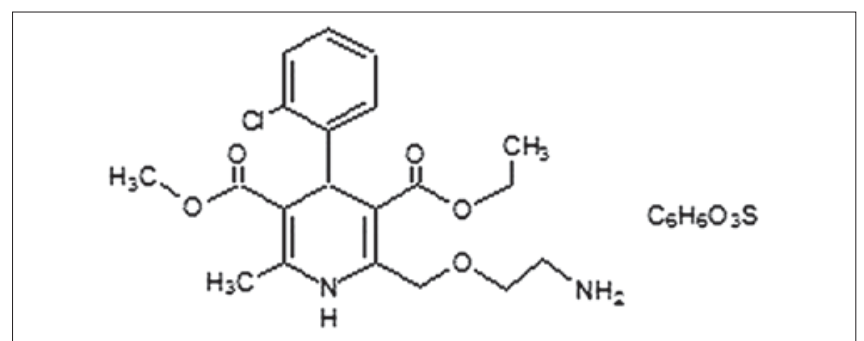

Figure 1: Structure of amlodipine

mass spectrometry (EI-MS), ${ }^{[6,7]}$ and high-performance liquid chromatography (HPLC). ${ }^{[8-12]}$ Several HPLC procedures have been also reported for the analyses of amlodipine based on MS-MS detection by using tandem mass spectrometry. ${ }^{[13-16]}$ Olmesartan medoxomil (OLM), (5-methyl-2-oxo-1,3-dioxolen-4-yl) methoxy-4-(1-hydrox y-1-methylethyl)-2-propyl-1-\{4-[2-(tetrazol-5-yl)-phenyl] phenyl $\}$ methyl imidazol-5-carboxylate) [Figure 2], is a potent and selective angiotensin AT1 receptor blocker ${ }^{[17]}$ which has been approved for the treatment of hypertension in the United States, Japan, and European countries. The drug contains a medoxomil ester moiety and is cleaved rapidly by an endogenous esterase to release the active metabolite olmesartan. ${ }^{[18]} \mathrm{Up}$ to date, olmesartan has been determined in plasma and other biological fluids using HPLC coupled to fluorescent detection. ${ }^{[19,20]}$

As per literature survey, no analytical methods have been reported for the simultaneous quantitative analysis of OLM and AM in biological fluid. The aim of our study was to develop a rapid, simple, accurate, precise, sensitive, and reproducible HPLC method, which can be utilized in pharmacokinetic research.

\section{EXPERIMENTAL}

\section{Chemicals and reagents}

Olmesartan medoxomil (OLM) and amlodipine besylate (AM) were kindly supplied by Ajanta Pharma Limited (Mumbai). All chemicals and reagents were HPLC grade, methanol and acetonitrile, ammonium acetate, ethylene diamine tetra acetic acid (EDTA) (Merck, India).

\section{Instruments and chromatographic conditions}

A Shimadzu HPLC system (Japan) employed consisted of a model LC-20 AT pump, a model Rheodyne 7125 injector, and a model SPD-20A UV detector. The separation was performed on an analytical $250 \times 4.6 \mathrm{~mm}$ Eurospher $100^{-5} \mathrm{C} 18(5 \mu \mathrm{m}$, particle size) column. The wavelength was set at $239 \mathrm{~nm}$. The mobile phase was a mixture of

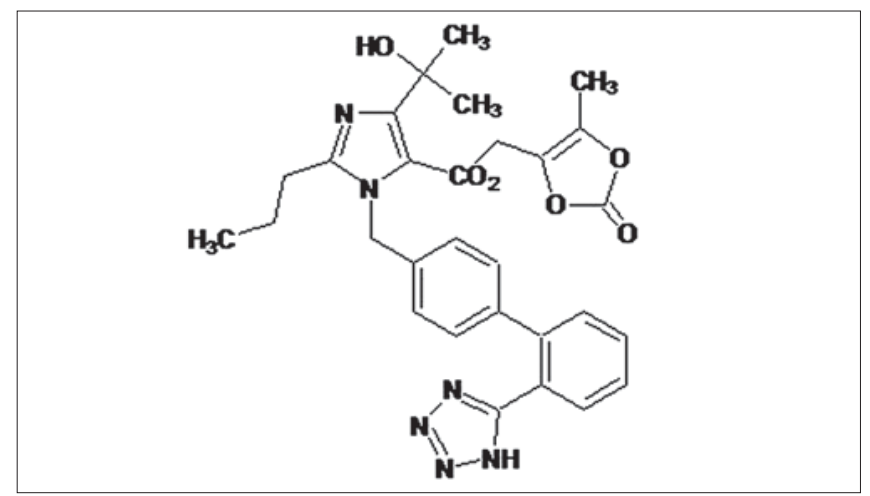

Figure 2: Structure of olmesartan

acetonitrile:0.05 M ammonium acetate buffer: $0.1 \mathrm{~mL}$ triethylamine at $\mathrm{pH} 6.8$ was selected at a flow rate of $1.0 \mathrm{~mL} / \mathrm{min}$. The mobile phase was prepared daily and degassed by ultrasonification before use.

\section{Preparation of standard stock solution}

The standard working concentration of OLM $(10 \mu \mathrm{g} / \mathrm{mL})$ and $\mathrm{AM}(10 \mu \mathrm{g} / \mathrm{mL})$ were prepared in the mobile phase.

\section{Biological samples}

The prepared suspension containing AM $(0.4 \mathrm{mg} / \mathrm{mL})$ and OLM $(1.6 \mathrm{mg} / \mathrm{mL})$ in $0.2 \%$ tween 80 were administered orally to Wistar rats (180-220 g) at a dose of $2 \mathrm{mg} / \mathrm{kg}$ (AM) and $8 \mathrm{mg} / \mathrm{kg}$ (OLM) body weight after overnight fasting. The blood samples were collected from the retrobulbar plexus into anticoagulant-treated polypropylene tubes from 0 to $12 \mathrm{~h}$ after drug administration. Blood samples collected were centrifuged immediately to separate the plasma. The plasma samples collected were stored at $-20^{\circ} \mathrm{C}$. The plasma samples then processed for drug recovery via solvent extraction.

\section{Samples preparation (extraction procedure)}

To $1000 \mu \mathrm{L}$ of plasma samples in a borosilicate glass tube were added $5 \mathrm{~mL}$ of HPLC grade acetonitrile. After vortex mixing for $10 \mathrm{~min}$ at room temperature, the samples were centrifuged at 10,500 $\mathrm{rpm}$ for $10 \mathrm{~min}$. The upper organic layer was transferred to a glass container and evaporated inside a vacuum oven at $40^{\circ} \mathrm{C}$. The dry residue was dissolved in $1 \mathrm{~mL}$ of the mobile phase. The mixture was sonicated well for $10 \mathrm{~min}$, and $20 \mu \mathrm{L}$ of this solution was injected into liquid chromatography.

\section{Stability}

Stability assessments were defined as the resistance to change in concentration of an analyte in plasma under 
specified conditions. The stability of OLM and AM in rat plasma was investigated by adding known amount of drug to blank plasma samples to give concentrations of 10,200, and $500 \mathrm{ng} / \mathrm{mL}$. These were stored at $-20^{\circ} \mathrm{C}$ and aliquots taken for 1 and 4 weeks for analysis.

\section{Calibration curve}

Linearity of instrument standard response was determined for each compound with different concentration calibration standards (final concentration ranging from 2 to $2500 \mathrm{ng} / \mathrm{mL}$ for $\mathrm{AM}$ and 8 to 10,000 ng/mL for OLM, with drug ratio maintaining constant 1:4). The calibration curves were constructed by plotting individual analyte peak area ratio as compared to the corresponding concentration and fitting these data in regression analysis. The calibration curves were constructed by the weighted regression method $(1 / x)$ of the peak area of OLM or AM vs. actual concentrations.

\section{RESULTS AND DISCUSSION}

\section{Method development}

Considering the efficiency of HPLC, an attempt has been made to develop a simple, accurate, precise, rapid, and economic method for the simultaneous estimation of OLM and AM in the biological method. Thus, the method described enables to the quantification of OLM and AM. The advantages lie in the simplicity of sample preparation and the low costs of reagents used. For the HPLC method development mobile phase consists of acetonitrile:0.05 M ammonium acetate buffer:0.1 mL triethylamine at $\mathrm{pH} 6.8$ at a flow rate of $1.0 \mathrm{~mL} / \mathrm{min}$. The optimum wavelength selected was $239 \mathrm{~nm}$. Under these chromatographic conditions described, OLM and AM peaks were well resolved. Endogenous plasma components did not give any interfering peaks. The average retention times of OLM and AM were 3.1 and 5.0 min, respectively. Chromatogram obtained after drug administration of OLM and AM in Wistar rats for blank plasma and plasma samples collected after 2.5, 6 and $10 \mathrm{~h}$ are shown in Figure 3.

\section{Calibration curve}

The calibration curve for the determination of OLM and AM in plasma was linear over the range 2-2500 and $8-10,000 \mathrm{ng} / \mathrm{mL}$ AM and OLM. The linearity of this method was statistically confirmed. For each calibration curve, the intercept was not statistically different from zero. The correlation coefficients $(\mathrm{R})$ for calibration curves were equal to or better than 0.997 . The relative standard deviation (RSD) values of the slope were equal to or better than $5 \%$. For each point of calibration standards, the concentrations were recalculated from the equation of the linear regression curves.

\section{Recovery study}

The relative analytical recovery for plasma at three different concentrations of OLM and AM was determined. Known amounts of drug were added to drug-free plasma in concentrations ranging from 0.002 to $10 \mu \mathrm{g} / \mathrm{mL}$. The average recovery was in between $50 \%$ and $90 \%$ for a linear concentration range. The results are given in Tables 1 and 2 for the intraday and interday study.

\section{Stability study}

In the short-term stability studies, precision and accuracy for the analyte was $<15 \%$ and $<8 \%$ for OLM, $<10 \%$ and $8 \%$ for AM, respectively. In the long-term stability studies, precision and accuracy for the analyte was $<7 \%$ and $<15 \%$

Table 1: Recovery studies for olmesartan medoxomil and amlodipine besylate (intraday) (RP-HPLC)

\begin{tabular}{|c|c|c|c|c|c|c|c|}
\hline $\begin{array}{l}\text { Sample } \\
\text { no. }\end{array}$ & Drug & $\begin{array}{l}\text { Concentration } \\
\text { added }(\mu \mathrm{g} \mathrm{mL})\end{array}$ & $\begin{array}{c}\text { Peak area } \\
\text { of standard }\end{array}$ & $\begin{array}{c}\text { Mean peak } \\
\text { area sample }^{\mathrm{a}}\end{array}$ & $\begin{array}{c}\% \\
\text { Recovery }\end{array}$ & \pm SD & $\mathrm{CV}$ \\
\hline \multirow[t]{2}{*}{1} & $\mathrm{AM}$ & 0.002 & 1888.81 & 1645.1 & 87.1 & 4.14 & 4.75 \\
\hline & OLM & 0.008 & 1211.4 & 1069.5 & 88.29 & 4.43 & 5.02 \\
\hline \multirow[t]{2}{*}{2} & $\mathrm{AM}$ & 0.01 & 3739 & 3203.4 & 85.68 & 1.29 & 1.51 \\
\hline & OLM & 0.04 & 2265.1 & 1966.2 & 86.8 & 2.51 & 2.89 \\
\hline \multirow[t]{2}{*}{3} & $\mathrm{AM}$ & 0.05 & 5695.2 & 4020 & 70.59 & 4.7 & 6.66 \\
\hline & OLM & 0.2 & 11325.9 & 8689.2 & 76.72 & 2.82 & 3.68 \\
\hline \multirow[t]{2}{*}{4} & $\mathrm{AM}$ & 0.2 & 10781 & 8858.74 & 82.17 & 2.93 & 3.57 \\
\hline & OLM & 80 & 44638.13 & 35049.84 & 78.52 & 6.49 & 8.27 \\
\hline \multirow[t]{2}{*}{5} & $\mathrm{AM}$ & 0.5 & 26952.5 & 17387.9 & 64.51 & 3.16 & 4.9 \\
\hline & OLM & 2 & 113259.5 & 70583.26 & 62.32 & 5.66 & 9.08 \\
\hline \multirow[t]{2}{*}{6} & $\mathrm{AM}$ & 1.5 & 80857.5 & 38064.76 & 47.08 & 5.15 & 10.9 \\
\hline & OLM & 6 & 275224.5 & 135510.9 & 49.24 & 7.54 & 15.3 \\
\hline \multirow[t]{2}{*}{7} & $\mathrm{AM}$ & 2.5 & 134762.5 & 52579.76 & 39.02 & 2.55 & 6.54 \\
\hline & OLM & 10 & 436810.5 & 181465.2 & 41.54 & 4.25 & 10.2 \\
\hline
\end{tabular}

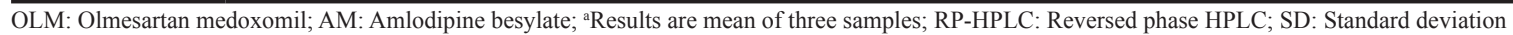




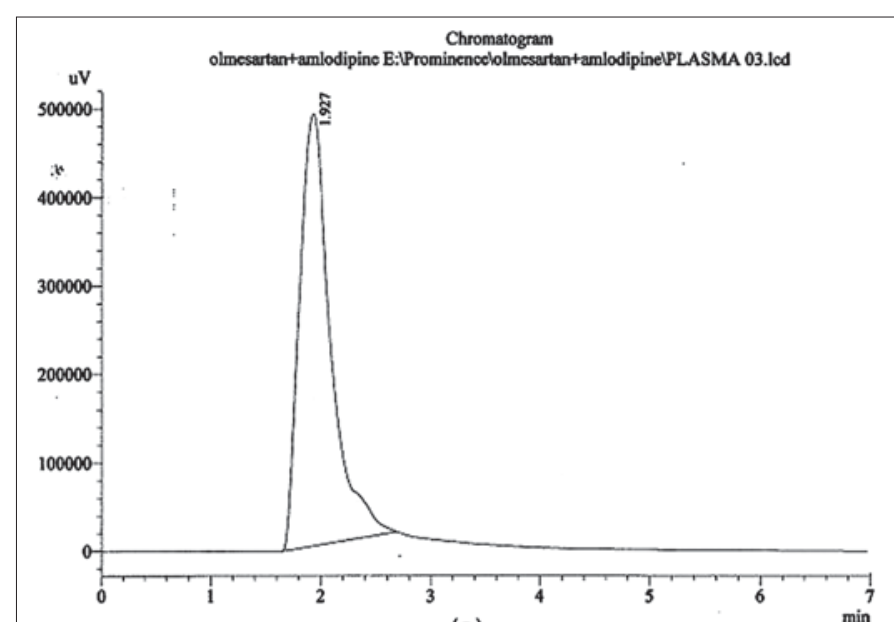

(a)

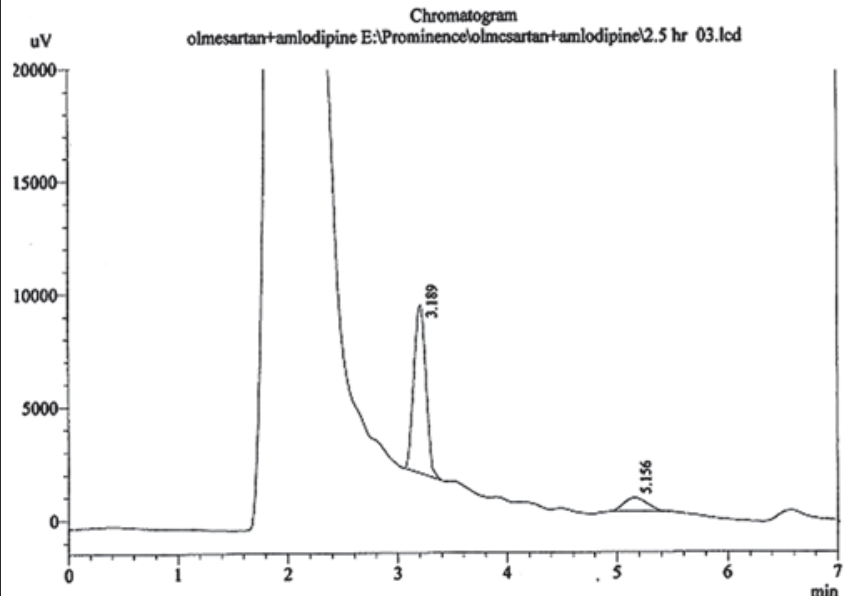

(c)
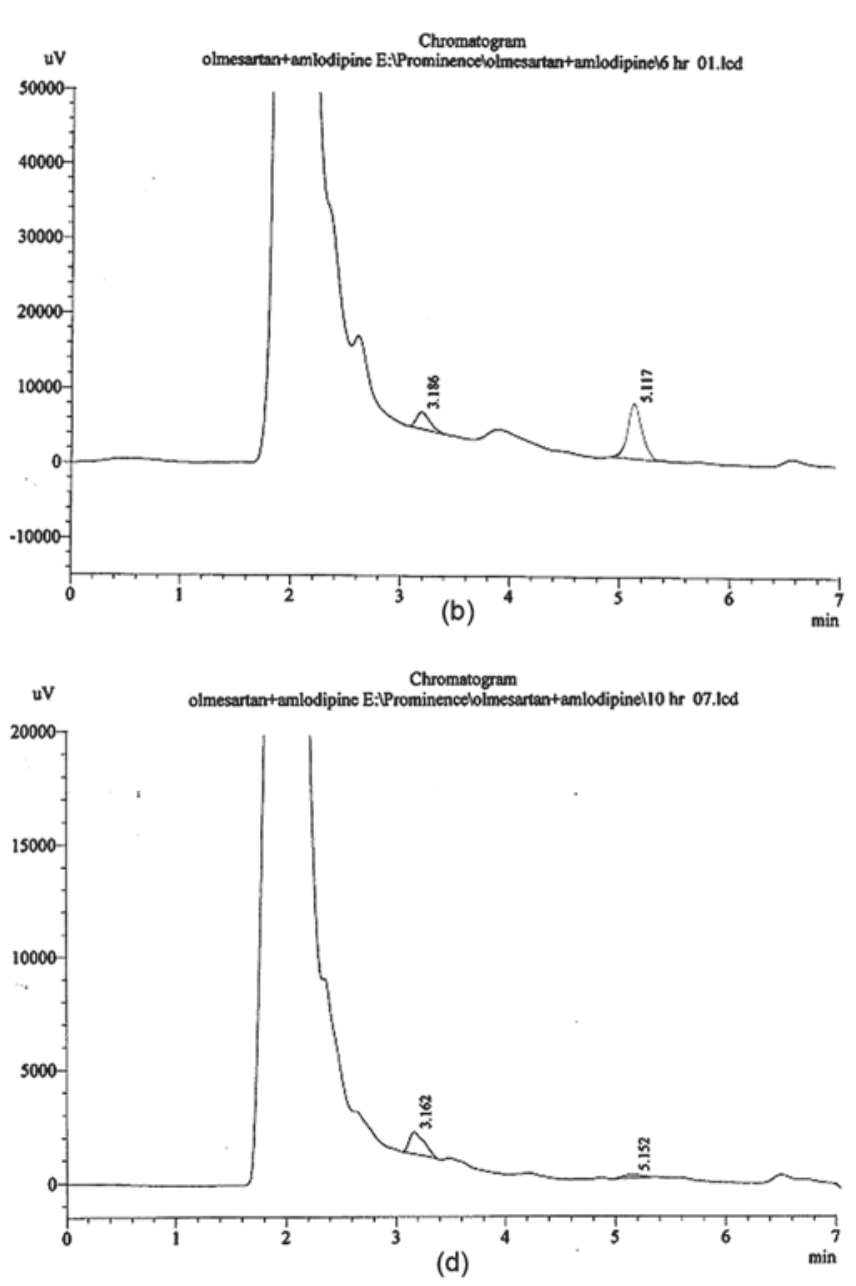

Figure 3: Chromatogram of blank plasma, OLM, and AM after oral administration in rat plasma

for OLM, $<12 \%$ and $18 \%$ for AM, respectively. The stability tests indicated that OLM and AM are stable in rat plasma over the period of 1 month. In addition, the stock solution remains stable for a duration of 1 month when stored at $4{ }^{\circ} \mathrm{C}$ expressed by the $\%$ variation $<2 \%$ for both OLM and AM. The results are given in Tables 3 and 4 for OLM and AM, respectively.

\section{Limit of detection}

The limit of detection (LOD) was defined, as the amlodipine concentration that produced a signal-to-noise ratio greater than 3 . The LOD in plasma was $2 \mathrm{ng} / \mathrm{mL}$ for $\mathrm{AM}$ and $8 \mathrm{ng} / \mathrm{mL}$ based upon this criterion. At this level, the RSD was lower than $15 \%$.

\section{Accuracy and precision}

Intraday and interday assay performed to evaluate precision ( $\%$ RSD) and accuracy. The coefficient of variation for intraday studies was between $2-14 \%$ and $3-17 \%$ for interday in rat plasma. The result suggests that within run and between run experiments, the precision and accuracy for the analyte met the acceptance criteria.

It does not require tedious derivatization or specialized detectors, making it readily amendable to routine laboratory use. However, this method is sensitive enough for drug monitoring and other purposes such as pharmacokinetic studies. We assessed the precision of the method by repeated analysis of plasma specimens containing known concentrations of amlodipine and olmesartan. The coefficients of variation were less than $15 \%$, which is acceptable for the routine measurement of OLM and AM. The results for intraday and interday precision and accuracy studies are given in Tables 5 and 6 .

\section{Pharmacokinetic study}

The results of pharmacokinetics analysis of OLM and AM are mentioned in Table 7. The mean plasma concentration-time curve of OLM and AM shows: 
Shah, et al.: Olmesartan medoxomil and amlodipine besylate in plasma

Table 2: Recovery studies for OLM and AM (interday) (RP-HPLC)

\begin{tabular}{|c|c|c|c|c|c|c|c|}
\hline $\begin{array}{l}\text { Sample } \\
\text { no. }\end{array}$ & Drug & $\begin{array}{r}\text { Concentration } \\
\text { added }(\mu \mathrm{g} / \mathrm{mL})\end{array}$ & $\begin{array}{c}\text { Peak area } \\
\text { of standard }\end{array}$ & $\begin{array}{c}\text { Mean peak } \\
\text { area sample }\end{array}$ & $\begin{array}{c}\% \\
\text { Recovery }\end{array}$ & \pm SD & $\mathrm{CV}$ \\
\hline \multirow[t]{2}{*}{1} & AM & 0.002 & 1789.56 & 1726.7 & 96.48 & 3.18 & 3.3 \\
\hline & OLM & 0.008 & 1045.65 & 1079.4 & 103.23 & 3.28 & 3.18 \\
\hline \multirow[t]{2}{*}{2} & $\mathrm{AM}$ & 0.5 & 25478.45 & 18597 & 72.98 & 5.14 & 7.05 \\
\hline & OLM & 2 & 112457.48 & 72914 & 64.83 & 7.24 & 11.2 \\
\hline \multirow[t]{2}{*}{3} & $\mathrm{AM}$ & 2.5 & 132486.97 & 53425 & 40.32 & 1.45 & 3.62 \\
\hline & OLM & 10 & 437849.98 & 259467 & 59.25 & 10.27 & 17.3 \\
\hline
\end{tabular}

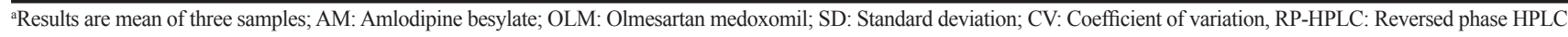

Table 3: Stability of OLM in rat plasma (RP-HPLC)

\begin{tabular}{|c|c|c|c|c|c|c|c|}
\hline \multirow{2}{*}{$\begin{array}{l}\text { Sample concentration (ng } \mathbf{~ m L}) \\
\text { Short-term stability for } 24 \mathrm{~h} \text { in } \mathrm{pl}\end{array}$} & \multicolumn{3}{|c|}{ Concentration found (\%) } & \multirow[t]{2}{*}{ \pm SD } & \multirow[t]{2}{*}{ Mean concentration $(\%)^{\mathrm{a}}$} & \multirow[t]{2}{*}{$\mathrm{CV}$} & \multirow[t]{2}{*}{$\%$ Deviation (inaccuracy) } \\
\hline & & & & & & & \\
\hline 10 & 124.5 & 101.5 & 95.2 & 15.42 & 107.06 & 14.4 & 7.06 \\
\hline 200 & 91.62 & 101.18 & 100.9 & 5.44 & 97.9 & 5.55 & 2.1 \\
\hline 500 & 97.25 & 97.62 & 102.57 & 2.97 & 99.14 & 2.99 & 0.852 \\
\hline \multicolumn{8}{|c|}{ Long-term stability for 1 month in plasma $\left(-20^{\circ} \mathrm{C}\right)$} \\
\hline 10 & 96.5 & 88.4 & 101.12 & 6.43 & 95.34 & 6.75 & 4.64 \\
\hline 200 & 87.82 & 80.12 & 90.67 & 5.45 & 86.20 & 6.33 & 13.79 \\
\hline 500 & 90.57 & 95.07 & 88.91 & 3.18 & 91.51 & 3.48 & 8.41 \\
\hline
\end{tabular}

${ }^{\mathrm{a} R e s u l t s ~ a r e ~ m e a n ~ o f ~ t h r e e ~ s a m p l e s, ~ S D: ~ S t a n d a r d ~ d e v i a t i o n ; ~ C V: ~ C o e f f i c i e n t ~ o f ~ v a r i a t i o n ; ~ O L M: ~ O l m e s a r t a n ~ m e d o x o m i l ; ~ R P-H P L C: ~ R e v e r s e d ~ p h a s e ~ H P L C ~}$

Table 4: Stability of AM in rat plasma (RP-HPLC)

\begin{tabular}{|c|c|c|c|c|c|c|c|}
\hline \multirow{2}{*}{\multicolumn{8}{|c|}{$\begin{array}{l}\text { Sample concentration (ng } \mathbf{~ m L}) \\
\text { Short-term stability for } 24 \mathrm{~h} \text { in plasma }\left(-20^{\circ} \mathrm{C}\right)\end{array}$}} \\
\hline & & & & & & & \\
\hline \multicolumn{8}{|c|}{10} \\
\hline 200 & 87.27 & 107.77 & 92.12 & 10.714 & 95.72 & 11.1 & 4.3 \\
\hline 500 & 97.89 & 88.51 & 94.24 & 4.72 & 93.54 & 5.05 & 7.58 \\
\hline \multicolumn{8}{|c|}{ Long-term stability for 1 month in plasma $\left(-20^{\circ} \mathrm{C}\right)$} \\
\hline 10 & 97.89 & 84.5 & 89.4 & 6.77 & 90.59 & 7.47 & 9.4 \\
\hline 200 & 81.77 & 72.89 & 92.24 & 9.68 & 82.3 & 11.7 & 17.7 \\
\hline 500 & 84.62 & 95.93 & 82.53 & 7.20 & 87.69 & 8.2 & 12.3 \\
\hline
\end{tabular}

aResults are mean of three samples, AM: Amlodipine besylate; SD: Standard deviation; CV: Coefficient of variation; RP-HPLC: Reversed phase HPLC

Table 5: Data for accuracy and precision studies (I ntraday) (RP-HPLC)

\begin{tabular}{|c|c|c|c|c|c|c|c|}
\hline $\begin{array}{l}\text { Sample } \\
\text { no. }\end{array}$ & Drug & $\begin{array}{l}\text { Concentration } \\
\text { added }(\mu \mathrm{g} \mathrm{mL})\end{array}$ & $\begin{array}{l}\text { Peak area } \\
\text { of standard }\end{array}$ & $\begin{array}{c}\text { Mean concentration } \\
\text { found }^{\mathrm{a}}\end{array}$ & \pm SD & $\mathbf{C V}$ & $\%$ deviation \\
\hline \multirow[t]{2}{*}{1} & AM & 0.002 & 1888.81 & 0.0019 & 6.9 & 6.77 & -0.05 \\
\hline & OLM & 0.008 & 1211.4 & 0.0079 & 2.4 & 2.34 & -0.012 \\
\hline \multirow[t]{2}{*}{2} & $\mathrm{AM}$ & 0.01 & 3739 & 0.0099 & 6.0 & 5.51 & -0.01 \\
\hline & OLM & 0.04 & 2265.1 & 0.0396 & 5.6 & 5.46 & -0.01 \\
\hline \multirow[t]{2}{*}{3} & $\mathrm{AM}$ & 0.05 & 5695.2 & 0.051 & 3.3 & 3.25 & 0.028 \\
\hline & OLM & 0.2 & 11325.9 & 0.198 & 2.8 & 2.75 & -0.008 \\
\hline \multirow[t]{2}{*}{4} & $\mathrm{AM}$ & 0.2 & 10781 & 0.198 & 3.5 & 3.44 & -0.012 \\
\hline & OLM & 80 & 44638.1 & 0.78 & 7.0 & 7.03 & -0.99 \\
\hline \multirow[t]{2}{*}{6} & $\mathrm{AM}$ & 0.5 & 26952.5 & 0.52 & 4.8 & 5.07 & 0.0304 \\
\hline & OLM & 2 & 113260 & 1.95 & 7.5 & 6.95 & -0.022 \\
\hline \multirow[t]{2}{*}{7} & $\mathrm{AM}$ & 1.5 & 80857.5 & 1.54 & 10.9 & 12.16 & 0.028 \\
\hline & OLM & 6 & 275225 & 5.7 & 15.3 & 13.29 & -0.0497 \\
\hline \multirow[t]{2}{*}{8} & $\mathrm{AM}$ & 2.5 & 134763 & 2.54 & 6.54 & 6.47 & 0.015 \\
\hline & OLM & 10 & 436811 & 10.66 & 10.2 & 11.13 & 0.065 \\
\hline
\end{tabular}

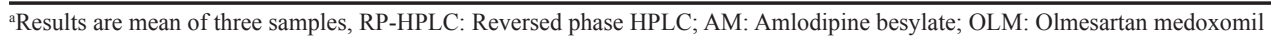

Plasma concentration reached a maximum $2 \mathrm{~h}$ and $6 \mathrm{~h}$ for OLM and AM, after dosing with a level of 8 and $2 \mathrm{mg} / \mathrm{kg}$ body weight of OLM and AM, respectively. The value of pharmacokinetic parameters such as $t_{1 / 2}$,
$\mathrm{C}_{\max }$ and $\mathrm{k}_{\mathrm{el}}$ obtained reveals that there was less difference in the profile of a individual drug when administered simultaneously in a single oral dosage form. These results are agreement with the previous reports..$^{[1,21,22]}$ Plasma 
Shah, et al.: Olmesartan medoxomil and amlodipine besylate in plasma

Table 6: Data for accuracy and precision studies (interday) (RP-HPLC)

\begin{tabular}{|c|c|c|c|c|c|c|c|}
\hline $\begin{array}{l}\text { Sample } \\
\text { no. }\end{array}$ & Drug & $\begin{array}{l}\text { Concentration } \\
\text { added }(\mu \mathrm{g} / \mathrm{mL})\end{array}$ & $\begin{array}{c}\text { Peak area } \\
\text { of standard }\end{array}$ & $\begin{array}{l}\text { Mean concentration } \\
\text { found }^{\mathrm{a}}\end{array}$ & \pm SD & $\mathrm{CV}$ & $\begin{array}{c}\% \\
\text { Deviation }\end{array}$ \\
\hline \multirow[t]{2}{*}{1} & $\mathrm{AM}$ & 0.002 & 1789.56 & 0.0021 & 3.18 & 5.2 & 0.05 \\
\hline & OLM & 0.008 & 1045.65 & 0.0079 & 3.28 & 3.7 & -0.0125 \\
\hline \multirow[t]{2}{*}{2} & $\mathrm{AM}$ & 0.5 & 25478.45 & 0.554 & 5.14 & 2.15 & 0.108 \\
\hline & OLM & 2 & 112457.48 & 2.338 & 7.24 & 2.9 & 0.169 \\
\hline \multirow[t]{2}{*}{3} & $\mathrm{AM}$ & 2.5 & 132486.97 & 2.7531 & 1.45 & 5.64 & 0.101 \\
\hline & OLM & 10 & 437849.98 & 12.859 & 10.27 & 2.96 & 0.28 \\
\hline
\end{tabular}

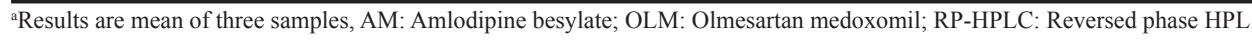

Table 7: Pharmacokinetic parameters of a single oral administration of OLM and AM in combined dosage form in Wistar rats

\begin{tabular}{lcc}
\hline Parameters & \multicolumn{2}{c}{ Drug administered } \\
\cline { 2 - 3 } & OLM & AM \\
\hline $\mathrm{t}_{\max }(\mathrm{hrs})$ & 6 & 2 \\
$\mathrm{C}_{\max }(\mu \mathrm{g} / \mathrm{mL})$ & 0.807 & 0.597 \\
$\mathrm{AUC}_{0-\mathrm{t}}(\mu \mathrm{g} / \mathrm{mL} / \mathrm{hrs})$ & 3.8165 & 3.5973 \\
$\mathrm{AUC}_{\mathrm{INF}}(\mu \mathrm{g} / \mathrm{mL} / \mathrm{hrs})$ & 14.6869 & 18.3447 \\
$\mathrm{t}_{1 / 2}(\mathrm{hrs})$ & 0.7473 & 0.9076 \\
$\mathrm{CL}(\mu \mathrm{L} / \mathrm{hr})$ & 2091.88 & 554.915 \\
$\mathrm{AUMC}$ & 14.5854 & 18.3447 \\
$\left.\mathrm{AUMC}_{\mathrm{IAST}}\left(\mu \mathrm{gg} / \mathrm{mL}^{\mathrm{N}}\right) \mathrm{hr}^{2}\right)$ & 14.7066 & 18.4353 \\
$\mathrm{MRT}_{\mathrm{LAST}}(\mathrm{hrs})$ & 3.8216 & 5.0995 \\
$\mathrm{MRT}_{\mathrm{INF}}(\mathrm{hrs})$ & 3.8404 & 5.115 \\
\hline
\end{tabular}

*Results are mean of three samples, OLM: Olmesartan medoxomil; AM: Amlodipine besylate; AUC: Area under curve; CL: Drug clearance; AUMC: Area under the moment curve

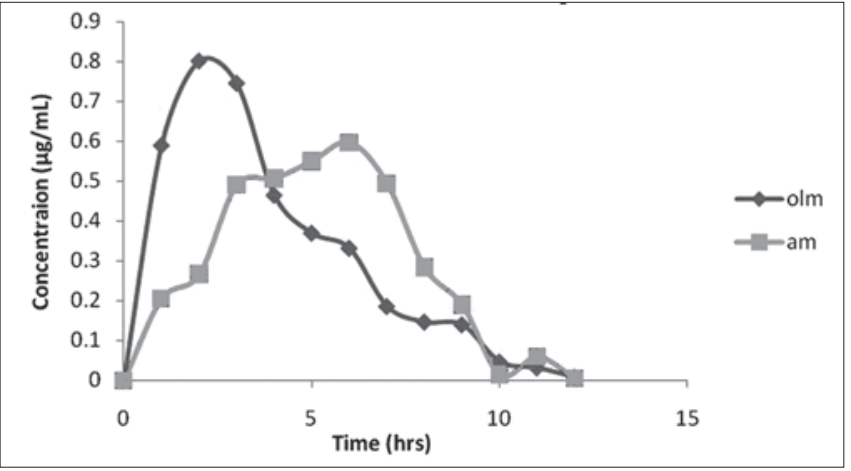

Figure 4: Plasma time profile curve

concentration-time profile curve following a single oral administration of OLM and AM in a combined dosage form in Wistar rats is shown in Figure 4.

\section{CONCLUSION}

The HPLC method presented is direct, simple, selective, reproducible, sensitive, and linear. The procedure was successfully applied to the simultaneous determination of the studied compounds in biological fluid without any interference from the additives and endogenous substances. The procedure was fully validated to meet the requirements of the food and drug administration center for drug evaluation and research guidelines for bioanalytical method validation. ${ }^{[23]}$ These methods are well-suited for routine application in the quality control laboratories and clinical laboratories because of the simplicity, economic, accuracy, sensitivity, and reproducibility. The HPLC method is applicable to pharmacokinetics studies of OLM and AM in rats. This method can also be used to study the mechanism of metabolism of OLM and AM. ${ }^{[2]}$

\section{ACKNOWLEDGMENTS}

The authors are thankful to Dr. D. R. Chaple, Principal, J. L. Chaturvedi College of Pharmacy, Nagpur for providing laboratory facilities. The authors also wish to thank Mr. Anwar Daud, Managing Director, Zim Laboratories Ltd., Nagpur, for providing facilities and environment conducive for an ideal research to flourish.

\section{REFERENCES}

1. Arrowsmith JE, Campbell SF, Cross PE, Stubbs JK, Burges RA, Gardiner DG, et al. Long-acting dihydropyridine calcium antagonists. J Med Chem 1986;29:1696-702

2. Abernethy D. The pharmacokinetic profile of amlodipine. Am Heart J 1989;118:1100-3

3. Meredith P, Elliott H. Clinical pharmacokinetics of amlodipine. Clin Pharmacokinet 1992;22:22-31.

4. Krol G, Noe A, Yeh S, Raemsch K. Gas and liquid chromatographic analyses of nimodipine calcium antagonist in blood plasma and cerebrospinal fluid. J Chromatogr 1984;305:105-18.

5. Bereford A, MaCrae P, Stopher D, Wood B. Analysis of amlodipine in human plasma by gas chromatography. J Chromatogr 1987;420:178-83.

6. Higuchi S, Kawamura S. Specific determination of plasma nicardipine hydrochloride levels by gas chromatography-mass spectrometry. J Chromatogr 1981;223:341-9.

7. Maurer HH, Arlt JW. Screening procedure for detection of dihydropyridine calcium channel blocker metabolites in urine as part of a systematic toxicological analysis procedure for acidic compounds by gas chromatography-mass spectrometry after extractive methylation. J Anal Toxicol 1999;23:73-80.

8. Shimooka K, Sawada Y, Tatematsu H. Analysis of amlodipine in serum by a sensitive high-performance liquid chromatographic method with amperometric detection. J Pharm Biomed Anal 1989;7:1267-72.

9. Pollen K, Yeung F, Mosher S, Pollak P. Liquid chromatography assay for amlodipine: Chemical stability and pharmacokinetics in rabbits. J Pharm Biomed Anal 1991;9:565-71.

10. Josefsson M, Norlander B. Coupled-column chromatography on a Chiral-AGP phase for determination of amlodipine enantiomers in human plasma: An HPLC assay with electrochemical detection. J Pharm Biomed Anal 1996;15:267-77.

11. Tatar S, Atmaca S. Determination of amlodipine in human plasma by 
high-performance liquid chromatography with fluorescence detection. J Chromatogr B 2001;758:305-10.

12. Bahrami G, Mirzaeei S. Simple and rapid HPLC method for determination of amlodipine in human serum with fluorescence detection and its use in pharmacokinetic studies. J Pharm Biomed Anal 2004;36:163-8.

13. Zhong D, Chen X, Gu J, Li X, Guo J. Applications of liquid chromatographytandem mass spectrometry in drug and biomedical analyses. Clin Chim Acta 2001;313:147-50.

14. Chen L, Zhou L, Shen M, Ma A. Simultaneous determination and pharmacokinetic study of metformin and rosiglitazone in human plasma by HPLC-ESI-MS. J Chromatogr Sci 2011;49:94-100.

15. StreelB,Laine C,ZimmerC, Sibenaler R, Ceccato A. Enantiomeric determination of amlodipine in human plasma by liquid chromatography coupled to tandem mass spectrometry. J Biochem Biophys Methods 2002;54:357-68.

16. Rojanasthien N, Teekachunhatean S, Jakob K, Gaupp M, Arnold P, Chaichana $\mathrm{N}$, et al. Bioequivalence study of generic amlodipine in healthy Thai male volunteers. Int J Clin Pharmacol Ther 2004;42:330-5.

17. Koga K, Yamagishi S, Takeuchi M, Inagaki Y, Amano S, Okamoto T, et al. CS-866, a new angiotensin II type 1 receptor antagonist, ameliorates glomerular anionic site loss and prevents progression of diabetic nephropathy in Otsuka Long-Evans Tokushima fatty rats. Mol Med 2002;8:591-9.

18. Schwocho L, Masonson H. Pharmacokinetics of CS-866, a new angiotensin II receptor blocker, in healthy subjects. J Clin Pharmacol 2001;41:515-27.

19. Nakamura H, Inoue T, Arakawa N, Shimizu Y, Yoshigae Y, Fujimori I, et al.
Pharmacological and pharmacokinetic study of olmesartan medoxomil in animal diabetic retinopathy models. Eur J Pharmacol 2005;512:239-46.

20. Sellin L, Stegbauer J, Laeis P, Rump LC. Adding hydrochlorothiazide to olmesartan dose dependently improves 24 -h blood pressure and response rates in mild-to-moderate hypertension. J Hypertens 2005;23:2083-92.

21. Abernethy DR. The pharmacokinetic profile of amlodipine. Am Heart J 1989;118:1100-3.

22. Carvalho M, Oliveira CH, Mendes GD, Sucupira M, Moraes ME, De Nucci G. Amlodipine bioequivalence study: Quantification by liquid chromatography coupled to tandem mass spectrometry. Biopharm Drug Dispos 2001;22:383-90.

23. US Department of Health and Human Services Food and Drug Administration, Guidance for Industry: Bioanalytical Method validation. US Department of Health and Human Services: Rockville, MD; 2001.

24. Zarghi A, Foroutan SM, Shafaati A, Khoddam A. Validated HPLC method for determination of amlodipine in human plasma and its application to pharmacokinetic studies. Farmaco 2005;60:789-92.

How to cite this article: Shah SK, Asnani AJ, Kawade DP, Dangre SC, Arora SK, Yende SR. Simultaneous quantitative analysis of olmesartan medoxomil and amlodipine besylate in plasma by high-performance liquid chromatography technique. J Young Pharmacists 2012;4:88-94.

Source of Support: Nil, Conflict of Interest: None declared.

\section{Author Help: Reference checking facility}

The manuscript system (www.journalonweb.com) allows the authors to check and verify the accuracy and style of references. The tool checks the references with PubMed as per a predefined style. Authors are encouraged to use this facility, before submitting articles to the journal.

- The style as well as bibliographic elements should be $100 \%$ accurate, to help get the references verified from the system. Even a single spelling error or addition of issue number/month of publication will lead to an error when verifying the reference.

- Example of a correct style Sheahan P, O'leary G, Lee G, Fitzgibbon J. Cystic cervical metastases: Incidence and diagnosis using fine needle aspiration biopsy. Otolaryngol Head Neck Surg 2002;127:294-8.

- Only the references from journals indexed in PubMed will be checked.

- $\quad$ Enter each reference in new line, without a serial number.

- Add up to a maximum of 15 references at a time.

- If the reference is correct for its bibliographic elements and punctuations, it will be shown as CORRECT and a link to the correct article in PubMed will be given.

- If any of the bibliographic elements are missing, incorrect or extra (such as issue number), it will be shown as INCORRECT and link to possible articles in PubMed will be given. 